\title{
Comparison of jet pipe servo valve with flapper nozzle servo valve
}

\author{
Pham Xuan Hong Son, Tran Thien Phuc
}

\begin{abstract}
Electro-hydraulic servo valves (EHSVs) serve as an interface between electrical devices and hydraulic systems. They are capable of converting low power electrical input into movement of a spool to control precisely high power, low speed hydraulic actuators. Nowadays, jet pipe electro-hydraulic servo valve and flapper nozzle electro-hydraulic servo valve are typical two-stage control flow servo valve and are the most popular in use. This paper recommends and compares characteristics, working principle and structure for two kinds of servo valve. Besides, the simulation was carried out in a commercially software of Ansys, hence some features of jet pipe servo valve such as outstanding advantages of working feature or reliability are analysed.
\end{abstract}

Index Terms - jet pipe servo valve, flapper nozzle servo valve, comparison, electro-hydraulic servo valve.

\section{INTRODUCTION}

$\mathrm{N}$ owadays, jet pipe electro-hydraulic servo valve and flapper nozzle servo valve are two kinds of servo valve which are the most popular in application for air-force, aviation industry or universe industry. However, to distinguish clearly about structure and working principle between jet pipe servo valve and flapper nozzle servo valve was not shown. Therefore, this paper is proposed.

\section{WORKING PRINCIPLE OF SERVO VALVE.}

\subsection{Flapper nozzle electro-hydraulic servo valve}

In Fig.1, sketch diagram of working principle for flapper-nozzle electro-hydraulic servo valve is

Manuscript Received on May 16th, 2016, Manuscript Revised February 22nd, 2017

Pham Xuan Hong Son was with Ho Chi Minh City University of Technology, Vietnam National University - Ho Chi Minh City, e-mail: pxhongson@gmail.com.

Tran Thien Phuc now with the Faculty of Mechanical Engineering, Ho Chi Minh City University of Technology, Vietnam National University - Ho Chi Minh City, Vietnam. (e-mail: ttphuc.rectie@hcmut.edu.vn). shown. It is mainly included torque motor, hydraulic amplifier of flapper-nozzle, power stage of valve spool and modulus of spring pole [1].

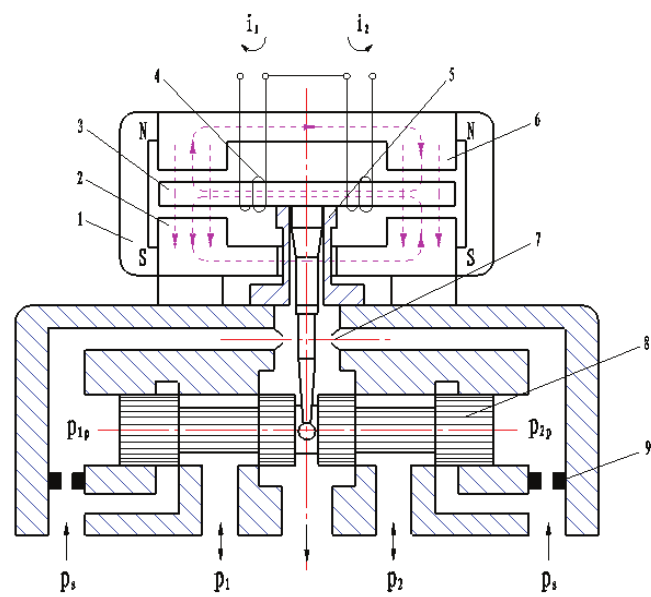

1. pernament armature, 2. lower magnet, 3. armature,

4. coil, 5 . spring pole, 6 . upper magnet, 7 . orifice,

8. valve spool, 9. fixed orifice.

Fig 1. Schematic of flapper nozzle servo valve

Working principle: when input an electric control signal to the coil of torque motor, immediately at two ends of armature, magnetic force is formed, as a result, modulus of the armature is deflected. Since deflection of flapper, one side of flapper-nozzle can do orifice become small, so force of hydraulic resistance is bigger and back-pressure from the orifice increases. And the other can do the orifice become large, force of hydraulic resistance is smaller, and back-pressure from orifice decreases. Like this, back-pressure from the orifice can be changed correlatively with the change of position of flapper. Because of interlinked between two ends of valve spool and nozzle chamber by back-pressure, valve spool moves. And valve spool draws small ball of spring pole, simultaneously feedback moment is formed at modulus of armature-flapper. When feedback moment gradually decreases to equal to magnetic moment, modulus of armature-flapper also moves gradually to null position. As a result, valve spool can stop anywhere that feedback moment equals to 
magnetic moment established from input an electric control signal. Therefore, the position of valve spool is directly proportional to magnitude of input electric control current. When oil supply pressure and load pressure are constant, the load flow at the output is proportional to position of valve spool [2].

\subsection{Jet pipe electro-hydraulic servo valve}

Fig.2 describes sketch diagram of working principle for jet pipe electro-hydraulic servo valve. Torque motor includes structure of permanent magnet, the flexure tube supporting at modulus of jet pipe, so torque motor and oil part are separated, and this kind is called dry-type. Jet amplifier is pre-stage, it includes jet pipe and receiver holes [3].

Working principle: When an electric control current inputs coil of torque motor, in torque motor, control flux is generated and mutual effect with permanent magnet flux. Thereupon, in the armature, torque is generated and it urges armature, the flexure tube and orifice deflecting together in small angle that is proportional to torque. Through deflection of high-speed jet of orifice, pressure of a chamber of receiver hole increases quickly, and pressure of the other decreases [4].

As a result, differential pressure is formed at two ends of valve spool, then valve spool moves until balance of magnetic moment and moment of yielding from feedback modulus is appeared, then the nozzle again returns to null position of receiver holes, and stops. Like this, displacement of valve spool is proportional to magnitude of control current, and the output flow of spool is also proportional to control current.

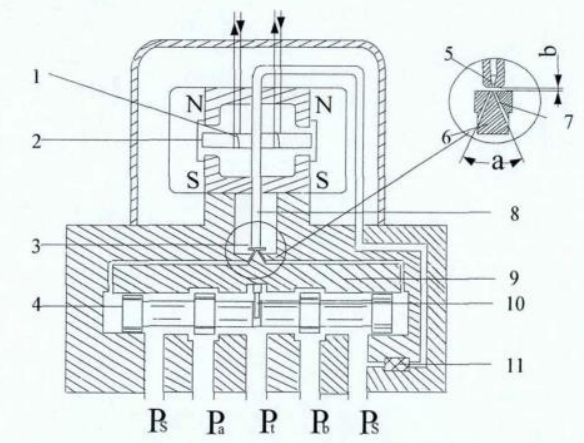

1. control coil, 2. armature, 3. orifice, 4. valve spool, 5. jet hole, 6. left receiver hole, 7. right receiver hole 8. jet pipe, 9. spool sleeve, 10. spring pole, 11. oil filter Fig 2. Schematic of jet pipe electro-hydraulic servo valve

\section{MAIN FEATURES.}

\subsection{Simulation in Ansys}

To compare the main features of flapper nozzle valve and jet pipe valve, Ansys software is used for simulation. 3D models of hydraulic amplifier of flapper nozzle valve and jet pipe valve are set up.

Fig. 3 is shown grids of 3D model of flapper nozzle valve and jet pipe valve. Grid of pressureflow diagram model of flapper nozzle servo valve is shown in Fig. 3(a), and the other is grid of pressure-flow diagram model of jet pipe servo valve.
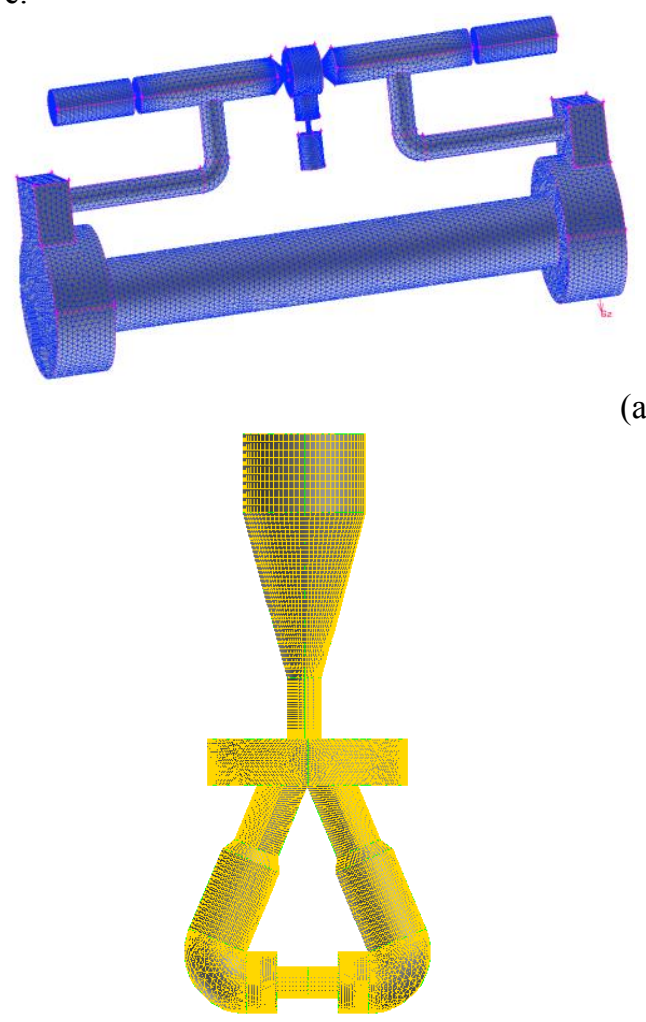

(a)

(b)

Fig 3. Grids of pressure-flow model

(a) Grids of pressure-flow model of flapper nozzle valve

(b) Grids of pressure-flow model of jet pipe valve

In this simulation, true size of hydraulic amplifier for servo valves is below:

Hydraulic amplifier of flapper-nozzle specifications can be described as follows: the nozzle diameter of $0.3 \mathrm{~mm}$, the length of $0.9 \mathrm{~mm}$, and the gap between the nozzle and the flapper is $0.04 \mathrm{~mm}$, while specifications of jet pipe hydraulic amplifier such as: nozzle diameter of $0.3 \mathrm{~mm}$, angle of receiver holes of 450 , diameters of receiver hole is $0.3 \mathrm{~mm}$, and the gap between the nozzle and the receiver holes is $0.5 \mathrm{~mm}$. 
The boundary conditions: the fluid lubrication is 0.0391 Pa.s, density of $850 \mathrm{~kg} / \mathrm{m}^{3}$. The inlet pressure of system is $21 \mathrm{MPa}$, and the outlet pressure of $0.1 \mathrm{MPa}$.

Results of simulation are below. Fig.4 and Fig.5 are gain characteristics of flow and pressure of jet pipe valve, and Fig.6 and Fig.7 are gain characteristics of flow and pressure of flappernozzle valve.

The flow gain characteristic of jet pipe valve is shown in Fig.4. The linear model of the relation between flow and control current is good. It is necessary to servo valve in manufacture. And it is almost linear model to flow gain of flapper nozzle valve, seeing Fig.6.

From Fig.5, the control current of jet pipe valve is small and the curve of pressure gain is very precipitous. Furthermore, its pressure gain characteristic gets to stabilize quickly while the pressure gain characteristic of flapper nozzle is not slope (seeing Fig.7). Through these, it can be seen that stableness of pressure gain of jet pipe valve is better than the other. With the small control current (about $1 \mathrm{~mA}$ ), the performance curve of jet pipe valve is stable, but it is not the same as that.

In addition, efficiency of pressure of jet pipe valve is higher, therefore its control force of is stronger than the other one.

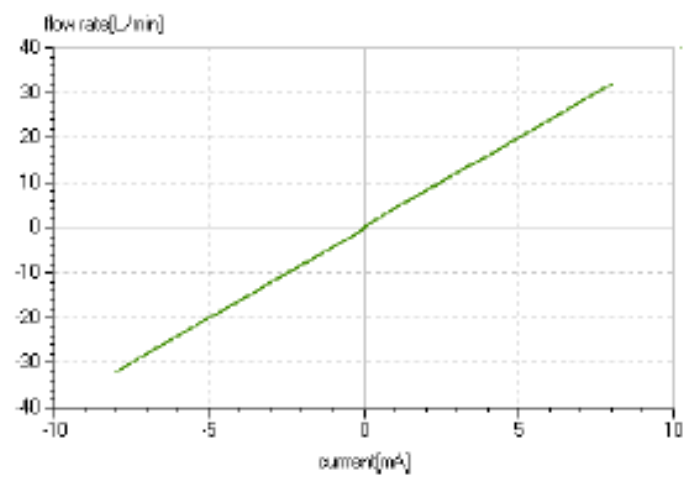

Fig 4 Flow gain characteristic of jet pipe valve

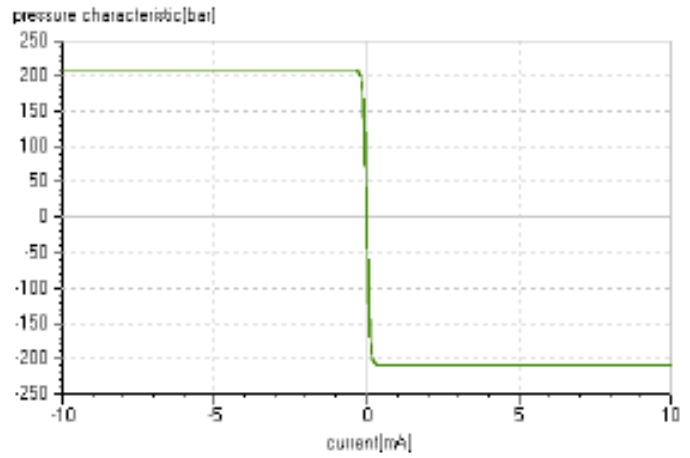

Fig 5 Pressure gain characteristic of jet pipe valve

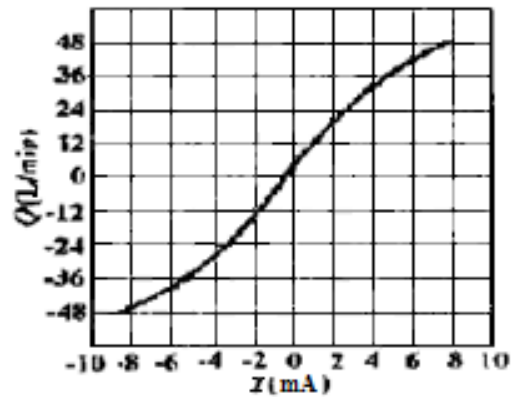

Fig 6 Flow gain characteristic of flapper nozzle valve

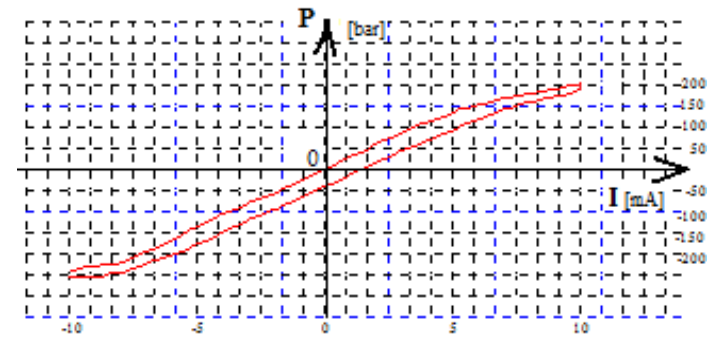

Fig 7 Pressure gain characteristic of flapper nozzle valve

\subsection{Discussion}

The biggest difference between jet pipe servo valve and flapper-nozzle servo valve is the change of fluid loop of flapper-nozzle through impedance to carry out control [3]. On the contrary, jet pipe servo valve uses high-speed jet of orifice to change pressure into kinetic energy that is obtained in two receiver holes, then to control this energy for spool action.

Comparison between jet pipe valve and flappernozzle valve, jet pipe mouth is big, so debris or dirty particles cause small harm, and anti-pollution capacity is very strong, seeing Fig.8.

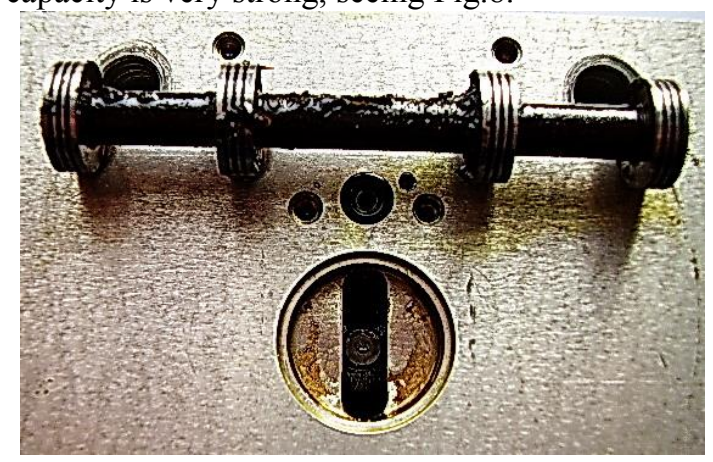

Fig 8. As result of this state, jet pipe valve is still good in operation

Moreover, pressure efficiency of jet pipe servo valve hydraulic amplifier and volumetric efficiency are large, it's over $70 \%$, sometimes its efficiency can be over $90 \%$.

Driving force from valve spool is strong, improve anti-pollution capacity. With the same 
sensitivity and distinguish ability, working performance of jet pipe valve at low pressure is better than flapper-nozzle valve, seeing Table 1.

$\underline{\text { Table } 1 \text { Comparison of jet pipe valve and flapper nozzle valve }}$

\begin{tabular}{l|c|c}
\hline \multicolumn{1}{c|}{ Parameters } & $\begin{array}{l}\text { Jet pipe } \\
\text { valve }\end{array}$ & $\begin{array}{l}\text { Flapper - } \\
\text { nozzle valve }\end{array}$ \\
\hline $\begin{array}{l}\text { Driving force }(\mathrm{kg}) \text { when } \\
\text { pressure of } 40 \mathrm{~kg} / \mathrm{cm}^{2} \\
\text { applies on the spool ends }\end{array}$ & 15.35 & 4.92 \\
\hline Control force of valve & big & small \\
\hline $\begin{array}{l}\text { Ability to work normally at } \\
\text { low pressure }\end{array}$ & $\geq 0.5 \mathrm{MPa}$ & $>3 \mathrm{MPa}$ \\
\hline \hline
\end{tabular}

In addition, at downstream of nozzle happens process of control in jet pipe valve, when the orifice is stucked completely by dirty particles, two receiver holes isn't supplied kinetic energy, thus two the ends of valve spool has nothing differential pressure, and force of bending deflection of flexure tube will do valve spool returning to null position, and servo valve can avoid large output-flow. But the jet pipe hydraulic amplifier and the characteristics of the whole valve is difficult to theoretical calculation and estimate, structure of torque motor and technology are complex, difficulty of process is much [4].

Comparison of flapper-nozzle servo valve with jet pipe servo valve, gain characteristics of flappernozzle is rather flat, can calculate and estimate while jet pipe is weaker, seeing Fig.4 to Fig.7.

But the gap between orifice and flapper can not exceed $1 / 16$ of orifice diameter, so the minimum size of this valve is rather small, and easily is stucked by dirty particles, thus it must be used cleanliness of oil for flapper-nozzle. Generally speaking, cleanliness of oil for flapper-nozzle is lower level of NAS6 , and cleanliness of oil through oil filter is lower $10 \mu \mathrm{m}$. Meanwhile, cleanliness of oil for jet pipe valve can higher level of NAS8, and particles through the oil filter can be bigger $25 \mu \mathrm{m}$. In addition, structure of flappernozzle includes two nozzles to control force, if one nozzle is stucked, it will increase pressure quickly at other side, thus valve spool will moves one side very much, and output-flow is the same direction, then actuators are maximum position in one side. Furthermore, pressure efficiency and volume efficiency of flapper-nozzle valve is about $50 \%$ ,and it is lower than jet pipe valve, seeing Fig.5 and Fig.7.

\section{STRUCTURE AND RELIABILITY.}

\subsection{Minimum size of pre-stage}

Anti-pollution capacity of servo valve is decided by minimum size, specially minimum size of oil channel often decides amplifier dimension. True size of hydraulic amplifier for jet pipe valve and flapper-nozzle valve is shown in Fig.9.
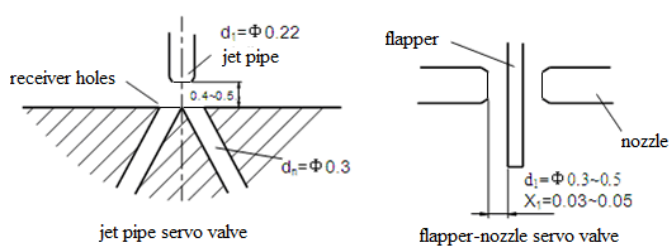

Fig 9. True size of hydraulic amplifier for servo valves

In flapper-nozzle valve, the gap between the nozzle and the flapper is about $0.03 \mathrm{~mm} \sim 0.05 \mathrm{~mm}$, and nozzle diameter is about $0.3 \mathrm{~mm} \sim 0.5 \mathrm{~mm}$. On the contrary, the gap in jet pipe is about $0.4 \mathrm{~mm} \sim$ $0.6 \mathrm{~mm}$, diameters of receiver hole is about $0.3 \mathrm{~mm}$, and jet pipe diameter is about $0.3 \mathrm{~mm}$.

\subsection{Abrasion}

At working, pre-stage of servo valve will generate abrasion, but abrasion and its change happen much to flapper-nozzle. This cause is as follows:

The min distance of the gap between nozzle and receiver holes in jet pipe is about $0.2 \mathrm{~mm} \sim 0.4 \mathrm{~mm}$, it is $5 \sim 10$ times bigger than the min gap between nozzle and flapper (about $0.03 \mathrm{~mm} \sim 0.05 \mathrm{~mm}$ ), therefore it does not happen stuck oil in jet pipe valve.

In jet field of jet pipe valve, the gap between nozzle end and receiver holes is bigger than nozzle diameter, it is about $1.5 \sim 2.5$ times bigger than, specially can be 3.5 times bigger. On the contrary, in jet field of flapper-nozzle valve, the gap is limited, it is $1 / 16$ of nozzle diameter, thus easily generate abrasion and its change, and abrasion is different and not symmetric for two sides of flapper, hence yielding zero drift. Furthermore, in jet pipe valve there is only one nozzle, and two receiver holes in symmetric position, so generation of abrasion is almost symmetric, and abrasion amount is also smaller than flapper-nozzle. When the gap between nozzle and receiver holes is 3.5 times smaller than nozzle diameter, even if high pressure oil scours at sunken cusp of receiver holes for long time, it still functions watershed. Besides, stability and reliability of jet pipe valve is better than flapper-nozzle valve. 
Currently, in the military fields of aviation and ship, jet pipe servo valve has generally been used to replace the kind of nozzle flapper, whose reliability directly determines the reliability and safety of the military equipment's electrohydraulic servo system [5].

\subsection{Structure of torque motor}

The whole torque motor parts of jet pipe valve are combined weld with press fit. Then they are eliminated strictly internal stress, solid structure is stable, zero drift is small, and can bear shock and vibration. Meanwhile, the torque motor of flappernozzle depends on 4 small screws of M3 that is fixed. After dispersing stress, suffering shock and oscillate, its zero drift is big. In addition, the armature of torque motor of jet pipe valve is supported on a pin, so it only revolves, and isn't bent, as a result flexure tube suffers great force, its fatigue becomes enhance, and life-span is longer.

\subsection{Size of second stage}

Fig.10 is shown the differences in operation between jet pipe electro-hydraulic servo valve and flapper-nozzle electro-hydraulic servo valve.

Control force of the pilot stage of jet pipe valve is bigger than flapper-nozzle valve, so diameter and stroke of the spool of jet pipe valve is also bigger and longer than the other.

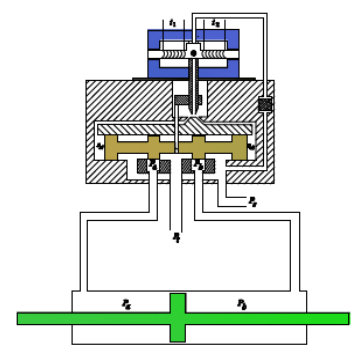

(a) Jet pipe valve

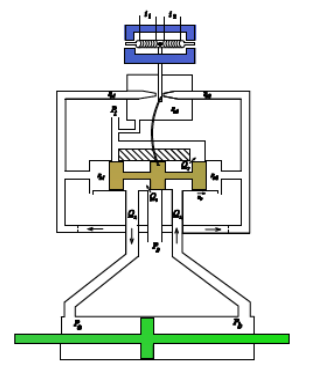

(b) Flapper-nozzle valve
Fig 10. Comparison of two servo valves

Table 2 shown valve spool specifications in comparison with two kinds in the pilot-stage.

From Table 2, it can be seen that the spool diameter of jet pipe valve is bigger than the other, thus its driving force is also bigger even though dirty oil is working, and the second stage still works smoothly, then reliability is higher. Moreover, the more long spool stroke, the more life-span of the spool is long [6].

When jet pipe valve works in high-speed jet, abrasion will appear at the ports in the valve sleeve, and the change of flow characteristics will do, too. After working in long stroke, ratio of abrasion and stroke is smaller, then the change of flow area at the ports is smaller, too. Ratio of the change of flow characteristic and life-span is smaller, too.

Table 2. Specifications for two kinds of servo valve

\begin{tabular}{l|l|l}
\hline \multicolumn{1}{c|}{ Parameters } & \multicolumn{1}{c|}{$\begin{array}{c}\text { Jet pipe } \\
\text { valve }\end{array}$} & \multicolumn{1}{c}{$\begin{array}{c}\text { Flapper nozzle } \\
\text { valve }\end{array}$} \\
\hline Diameter of valve spool (mm) & 6.99 & 3.96 \\
\hline Valve spool stroke (mm) & 0.64 & 0.13 \\
\hline Control force of valve & big & small \\
\hline Dirty of oil & NAS 8 & $<$ NAS 6 \\
\hline $\begin{array}{l}\text { Dirty particle size through oil } \\
\text { filter }\end{array}$ & $25 \mu \mathrm{m}$ & $<10 \mu \mathrm{m}$ \\
\hline \hline
\end{tabular}

\section{WORKING PERFORMANCE.}

In jet pipe amplifier, the most value of benefit flow can obtain $90 \%$, and benefit pressure is over $80 \%$. Therefore, driving force formed from jet pipe amplifier is bigger much than the other.

In working condition of supply pressure is smaller than $0.5 \mathrm{MPa}$, jet pipe servo valve is still stable, but the other can not do [7].

Natural frequency without damping is very high in the pilot stage of jet pipe valve, it is over $500 \mathrm{~Hz}$ $\sim 700 \mathrm{~Hz}$. Dynamic response of jet pipe valve is rather, whereas dynamic response of the other is very good, that is strong point of flapper-nozzle valve.

\section{CONCLUSION}

Jet pipe servo valve is reliable and anti-pollution capacity is very good. Dynamic response of flapper-nozzle servo valve is good too. Therefore, kinds of servo valve is chosen by useful purposes.

\section{REFERENCES}

[1]. T. Wang, M.L. Cai, Kenji Kawashima, Toshihara Kagawa. Modelling of a Nozzle-Flapper Type Pneumatic Servo Valve Including the Influence of Flow Force [J]. International Journal of Fluid Power, 2005, 6(3): 33-43.

[2]. Li Lan, Gao YingJie. Research Performance Parameters of Hydraulic Flapper-nozzle Servo Valve [J]. Hydarulic and Pneumatic, 2008 (10), 69-73. (in Chinese).

[3]. Ji Hong, Wei LieJiang, etc. Investigation to the Flow of the Jet Pipe Amplifier in a Servo Valve [J]. Machine Tool and Hydraulics, 2008, 36 (10): 119-121. (in Chinese).

[4]. G. Zhou, Y. Qian, and T.Q.Lv. Reliability Analysis of Jet-tube Hydraulic Servo Valve Based on FMECA 
Method. Ship Engineering, Vol. 36, No. 4, pp. 57-60, 2014.

[5]. MOOG ATCHLEY controls material. http://www.moog.com

[6]. Mohieddine Jelali and Andreas Kroll. Hydraulic Servo Systems. Modelling, Identification and Control, September 2002.

[7]. IN-LHC Servo Valves Technical Characteristics.

Pham Xuan Hong Son, Faculty of Mechanical Engineering, Ho Chi Minh City University of Technology, Vietnam National University - Ho Chi Minh City.
Tran Thien Phuc is a Lecturer at the Department of Machine Design, Faculty of Mechanical Engineering, Ho Chi Minh City University of Technology, Vietnam National University - Ho Chi Minh City, Viet Nam. He received a Doctoral Degree from the Graduate School of Engineering at Pukyong National University, Korea in 2005. His research interests include: automatic control, robotics, manufacturing process. He get award for the best paper in ICASE 2003, Busan, Korea.

\section{So sánh van servo vòi phun với van servo bản chắn}

Phạm Xuân Hồng Sơn, Trần Thiên Phúc

Trường Đại học Bách Khoa, Đại học Quốc gia Thành phố Hồ Chí Minh

Tóm tắt- Van servo điện thủy lực giữ nhiệm vụ kết nối giữa các thiết bị điện với các hệ thống thủy lực. Chúng có khả năng biến đổi năng lượng điện thấp ở đầu vào thành chuyển động của con trượt van để điều khiển các cơ cấu chấp hành thủy lực có tốc độ thấp và nguồn năng lượng cao một cách chính xác. Hiện nay van servo vòi phun điện thủy lực và van servo vòi phun-bản chắn điện thủy lực là hai loại van servo điều khiển lưu lượng hai cấp điển hình được sử dụng phổ biến nhất. Bài báo này giới thiệu và so sánh các đặc điểm, nguyên lý làm việc và kết cấu của hai loại van servo này. Ngoài ra, thông qua mô phỏng các đặc tính làm việc của hai loại van servo bằng phần mềm Ansys, tiến hành phân tích những ưu thế nổi bật về đặc tính làm việc và độ tin cậy của van servo vòi phun được thực hiện.

Từ khóa- Van servo vòi phun; van servo tấm bản; so sánh van; van servo điện thủy lực. 